\title{
Practical estimation and distribution of diffuse pollutants arising from a watershed in Turkey
}

\author{
A. Tanik - D. Ozalp · D. Z. Seker
}

Received: 27 March 2011/Revised: 4 March 2012/Accepted: 13 March 2012/Published online: 18 December 2012

(c) CEERS, IAU 2012

\begin{abstract}
This study presents the diffuse pollution profile of a coastal watershed with respect to the dominating sector of agriculture including forestry. A rough estimation of the diffuse loads expressed by two major nutrients of nitrogen and phosphorous is realized by calculations based on unit loads obtained from the literature for each land-use activity. The key concern is to rank the different diffuse loads arising from the watershed. The major diffuse nitrogen loads are estimated to arise from agricultural activities with $54 \%$, followed by livestock breeding that contribute to the nitrogen budget by $11 \%$. Almost $7 \%$ of the nitrogen loads come from meadows and pasture, and $5 \%$ from forests. In the distribution of diffuse phosphorus loads, it is estimated that $48 \%$ of the loads arise from agricultural activities, and $18 \%$ from livestock breeding. Almost $14 \%$ of the phosphorous loads come from septic tank effluents; however, $13 \%$ of the loads are due to rural run-off. The future loads for 2028 and 2039 are also estimated; $30-40 \%$ decrease is foreseen in the agricultural pollutants and animal manure through the stepwise application of ecological agriculture and livestock breeding. The basic aim of this study is to put forth a practical methodology for estimating diffuse loads in a watershed for the decision-makers and local administrative authorities with especially limited available data. Through such, distribution of various diffuse loads becomes available among the administrative units composing the watershed.
\end{abstract}

A. Tanik $(\bowtie) \cdot$ D. Ozalp

Department of Environmental Engineering, Istanbul Technical

University, 34469 Maslak, Istanbul, Turkey

e-mail: tanika@itu.edu.tr

D. Z. Seker

Department of Geomatics Engineering, Istanbul Technical University, 34469 Maslak, Istanbul, Turkey
Keywords Agricultural activities - Diffuse loads · Land-use distribution - Nitrogen and phosphorous . Population

\section{Introduction}

Diffuse pollutants that arise due to various land-use activities in a watershed are transported to receiving water bodies in a diffuse manner at intermittent intervals through precipitation. Unlike point sources of pollutants, diffuse (non-point) sources are impossible to monitor at the point of origin and their abatement is focused rather on land and run-off management practices. Compliance monitoring is carried out on land rather than in water. Another important aspect of such sources is that the waste emissions and discharges cannot be measured in terms of effluent limitations (Novotny 2003).

Extent of diffuse waste emissions expressed by nutrients of nitrogen $(\mathrm{N})$ and phosphorous $(\mathrm{P})$ is related to certain uncontrollable climatic, geographic, geologic conditions, and may differ from place to place and from time to time (Campbell et al. 2004). In the estimation of diffuse loads, the essential factors to be determined are the areal values of each land-use activity, urban and rural population values and their future trends, climatic conditions and soil properties, and the precision of calculating such loads extending from simple practical calculations to complex watershed modelling studies (Debarry 2004; Behrendt and Dannowski 2005; Karpuzcu et al. 2008; Hoekstra et al. 2011). Detailed studies make use of modern technological tools like remote sensing (RS), Geographical Information Technologies (GIS), and non-point models to come up with more accurate diffuse load solutions (Borah and Bera 2003; Luzio 
et al. 2004; Erturk et al. 2007a; b; Chansheng and DeMarchi 2009; Wu et al. 2010; Kimwaga et al. 2011). Such studies will require time, money, and data; but they will lead to a better understanding of the transportation mechanism of pollutants on soil till they reach the water media, thus playing an important role in the determination of diffuse pollutants (Silgram et al. 2009). Besides, practical estimations can be achieved in a shorter period of time where available data are limited prior to focusing on detailed work. This study forms an example of how such calculations can be practiced especially in developing countries with the aim of putting forth the distribution of respective loadings containing various diffuse pollutants generated in a watershed.

The methodology of estimating diffuse nitrogen, $\mathrm{N}$, and diffuse phosphorous, $\mathrm{P}$, loads based on land-use activities will be explained. The distribution and estimation of current diffuse loads in the study area will be given on administrative basis to better illustrate the existing situation to the decision makers. Furthermore, control actions that might be considered for the watershed in the future will be referred and outlined.

Efforts to identify and estimate diffuse loads and their control in the short and long term form an integral part of river basin action plans that need to be completed in the short run according to the European Union (EU) enforcements. During the accession period, Turkey has to comply with the EU directives regarding water framework directive (WFD). The action plans will then form a basis for the preparation of watershed management plans. The methodology used in this paper is being used in determination of diffuse loads arising from all of the river basins of the country. Currently, the action plans of the top-priority 11 river basins, out of a total of 25 , have recently been completed by the end of 2010. Studies on the rest of 14 watersheds have recently started at the end of 2011, and corresponding action plans will be prepared within 2 years of time. The Eastern Black Sea Watershed of the country is among the ones that have not been yet studied (Fig. 1). Therefore, this watershed that has limited available data leading to determination of diffuse pollution profile is selected as the study area, where unit loads derived from the literature and data gathered from the field trips are used to estimate the various diffuse pollutant loads that might arise from different land-use activities. A modelling study to better evaluate the fate and behaviour of the diffuse loads on soil till they reach the water body and in the water is not covered within the scope of this study, as this is the initial step taken towards the identification and determination of the diffuse loads to be brought to the attention of decision makers and the local authorities. The key idea here is to highlight the roughly estimated emerging diffuse loads in a watershed which is not highly populated and industrialized, prior to more detailed research. The diffuse load distributions will be based on the overall watershed as well on the provinces constituting the watershed. The validation for confirming the assessment correctness will be demonstrated after conducting more detailed studies on the watershed in the coming years during the preparation of the watershed management plans.

Turkey, for the time being, has not published its national WFD yet and has not reached to a state of fulfilling the requirements of EU WFD that refers to 'good ecological status'. That is the main reason of acceleration in the efforts towards the preparation of watershed action plans. Thorough examination of the existing and previous water quality in the water bodies of watersheds that are not highly populated and industrialized is unfortunately lacking; this is due to the fact that emphasis is given more on to the comparatively industrialized and populated parts of the country that bear poor quality waters because of insufficient wastewater treatment systems, and lack of control and monitoring actions. Thus, limited information exists on both the quality and quantity of water bodies of this watershed to assess the carrying capacity of the water body by the expected quality. Thus, the linkage between the water quality and land-based pollution will not be covered in this study.

\section{Study area}

Eastern Black Sea Watershed is situated at the north eastern part of the country with a surface area of 2,490,320 ha and a population of 2,226,658 according to 2007 figures, where $56 \%$ constitutes the urban population and the remaining $44 \%$ the rural population. The distribution of the urban and rural population of the watershed within years is shown in Fig. 2a. The population density of the watershed ( 89 capita/ $\mathrm{km}^{2}$ ) represents the country's average of $91 \mathrm{capita} / \mathrm{km}^{2}$ (TUIK 2008). The watershed consists of land from ten provinces among which five have shares between 15 and $20 \%$. Trabzon and Rize provinces fully share a watershed area forming 19 and $16 \%$, respectively. Ordu Province has a share of $20 \%$, followed by Giresun with $18 \%$ and Gumushane with $15 \%$. The rest of the five provinces have minor contribution to the watershed with land varying between 1 and $5 \%$.

The major economic sector of the watershed is agriculture including the fishery and forestry and it is under the effect of typical Black Sea climate. The coastline receives high precipitation varying between 800 and $2,500 \mathrm{~mm}$, whereas the inner parts range within $400-800 \mathrm{~mm}$. Precipitation occurs all throughout the year with differences observed among seasons. The region receives the highest 
Fig. 1 The geographical location of the watershed and the sharing provinces
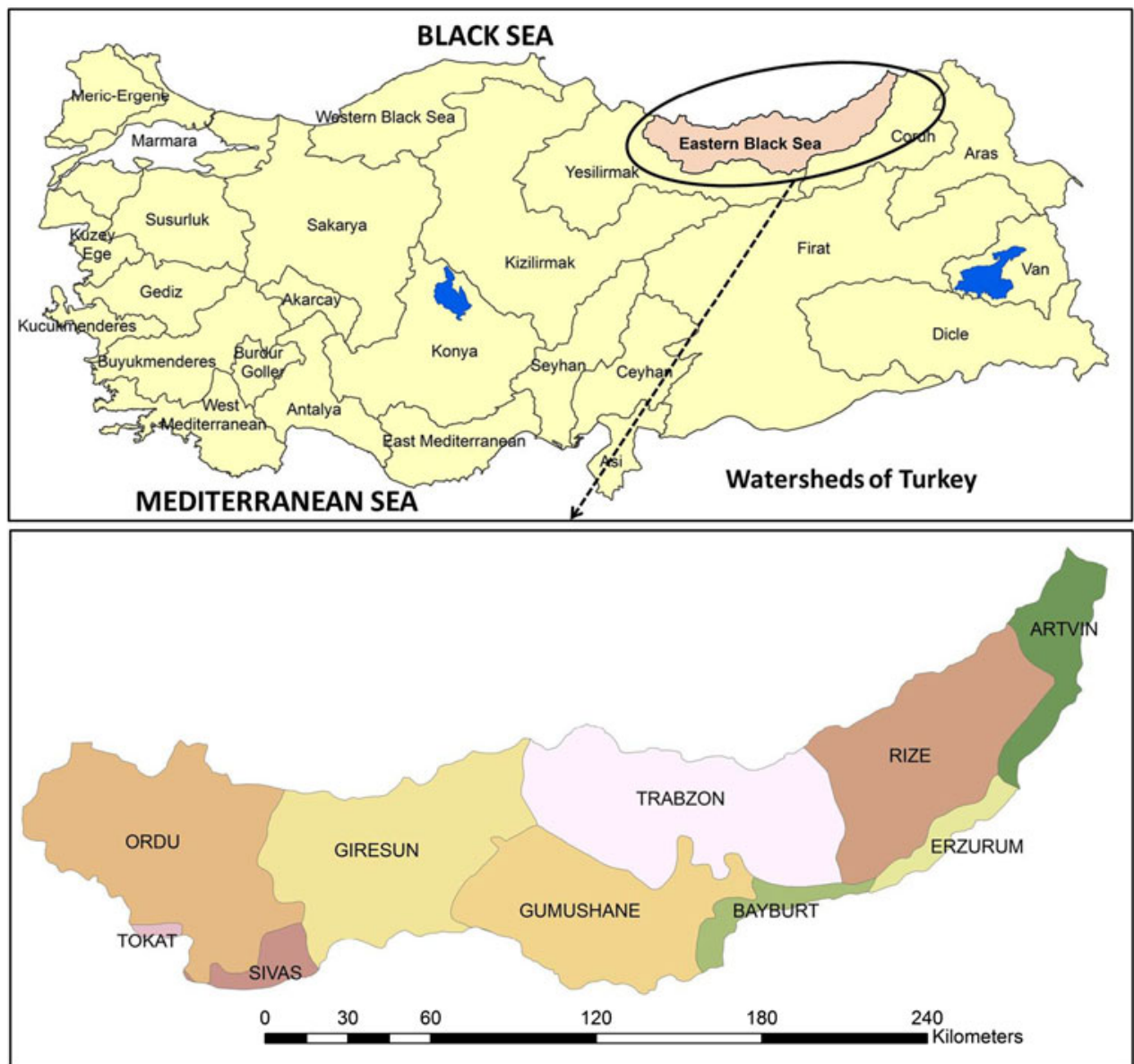

(a)

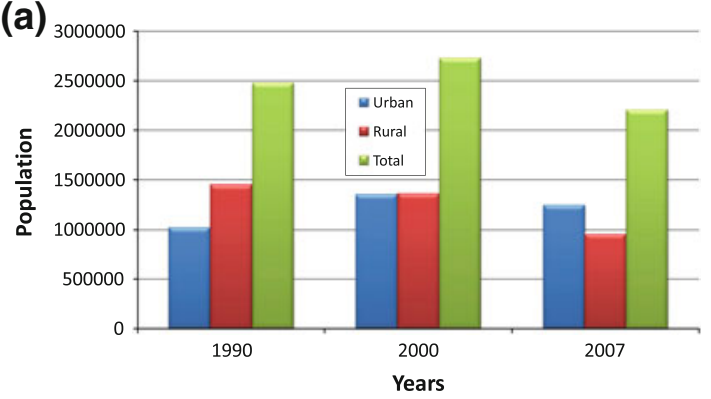

(b)

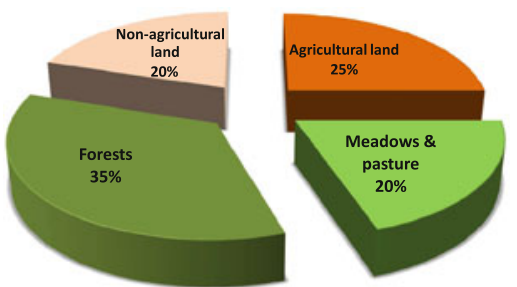

(c)

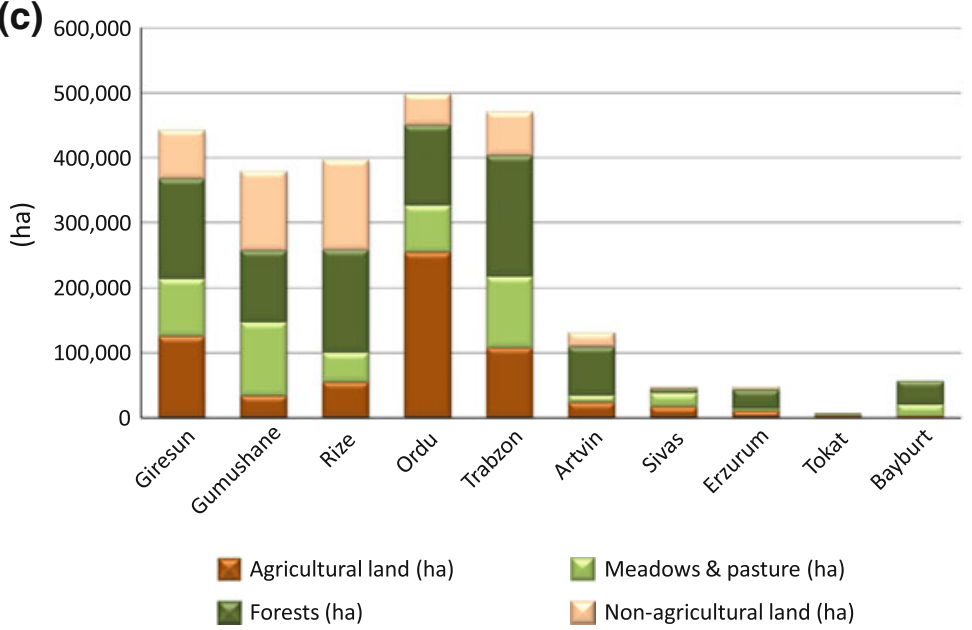

Fig. 2 a Population trend and its distribution among urban and rural population of the watershed, $\mathbf{b}$ Land-use distribution of the watershed, c Land-use distribution of provinces that constitute the watershed

precipitation in the country and is mostly known as a mountainous area with significant agricultural activities in the valleys.
The identification of diffuse pollutants and the corresponding data inventory stage is the fundamental part regarding the types of human-induced prevailing activities 
evolving such pollutants (ESCAP 1997). Therefore, determining the land-use and its distribution within the watershed is the initial step to be followed as the diffuse sources of pollutants in the watershed have not yet been identified and estimated. The environmental pollutants in the country are rather investigated in a province-based approach. Figure $2 b$ indicates the overall land-use distribution of the watershed, whereas Fig. 2c illustrates the land-use distribution of the watershed based on each of the sharing provinces.

It is important to note that the industry sector in the watershed is not as significant as the watersheds around the Sea of Marmara, and in the coastal watersheds situated along the Aegean Sea and the Mediterranean Sea.

\section{Materials and methods}

It is difficult to calculate the diffuse loads of pollutants arising from watersheds as they are distributed in a disperse manner, thus they are estimated based on either unit loads stated in the literature or through watershed modelling studies (Gurel et al. 2010; Tanik et al. 2010). In this watershed, the significant diffuse polluting sources arise from agricultural activities, livestock breeding, forests, meadows and pasture, urban runoff, rural runoff, atmospheric deposition including traffic emissions, dumpsite leachate, and septic tank effluents. The areal values of each land-use activity are obtained from the recent environmental situation reports of each of the participating province. Unfortunately, satellite imaginary of the watershed could not be obtained during the study to check the areal distribution of different land-use activities. Table 1 refers to the selected unit loads that have been determined after a thorough investigation of the prevailing climatic conditions, geological and hydrological survey, topography, and soil properties, together with other environmental characteristics of two neighbourhood watersheds of megacity Istanbul located along the Black Sea Coast (Dahl and Kurtar 1993; OEJV 1993) and of Keban Dam located at the inner Anatolia region (Saatci et al. 1999). Moreover, the loads determined for a watershed in Greece as a neighbouring country are also listed.

Diffuse loads from forests, meadows and pasture, urban and rural areas

The diffuse loads arising from forests, meadows and pasture, urban and rural land are calculated by multiplying the related areal values with the unit loads cited in the literature. In the selection of the appropriate unit loads, the climatic and geological conditions of the watershed of concern are important. Time and money consuming detailed studies are required for achieving representative unit loads based on different land-use activities, and these site-specific loads must be determined separately for each of the watersheds. Thus, the unit loads of forests, meadows and pasture, rural and urban land derived for the Istanbul region by Dahl and Kurtar (1993) and OEJV (1993) are used in the Eastern Black Sea Watershed considering the environmental similarities of the two regions.

\section{Diffuse loads from agricultural areas}

The agricultural return flows carry excess fertilizers applied on agricultural land. Thus, as an initial step during the calculation of the diffuse agricultural loads, the annual applied fertilizer amounts are obtained from the official agricultural authorities based on the districts of sharing provinces (ILEMOD 2007). As the areal values of each participating district are known, the active $\mathrm{N}$ and $\mathrm{P}$ applied per district of the province, and the unit fertilizer application values are calculated. Then, the total application loads are calculated for each of the districts. The crop uptake of nutrients varies within certain ranges; however, it would be ideal if all the applied nutrients are used by the crop. The crop uptakes highly depend on the climatic conditions, soil properties, type of crops produced, form of the fertilizer applied, and the method and frequency of application (Pittaway 2002). In fact, uptake rates range from 40 to $80 \%$ of $\mathrm{N}$ applied (Chapin III et al. 2002), and only 5-20\% of P applied (Salehi and Hajiboland 2008). As more fertilizers are applied, uptake becomes less efficient. In other words, the percentage of applied fertilizer taken up by plants goes down as application amounts go up, thereby increasing potential nutrient loss through run-off, leaching and volatilization in the form of gaseous nitrogen. Losses from leaching and runoff vary between 0.5 and $5 \%$ of the $\mathrm{P}$ applied, and between 5 and $30 \%$ of the $\mathrm{N}$ applied (Oenema and Roest 1998; Bottcher and Rhue 2000). In this study, the crop uptake values are taken as 50 and $20 \%$ for $\mathrm{N}$ and $\mathrm{P}$, respectively. Besides, the losses from the soil to the receiving water are accepted as $15 \% \mathrm{~N}$ and $5 \% \mathrm{P}$ applied. The rest $35 \% \mathrm{~N}$ and $75 \% \mathrm{P}$ fractions are considered to be lost through transportation reactions, such as ammonia volatilization, nitrification, denitrification, and $\mathrm{P}$ adsorption on soil. Table 2 summarizes the agricultural land of each of the sharing provinces, fertilizer applied per land of sharing province that lies within the boundaries of the watershed, and annual loss of excess fertilizer in terms of $\mathrm{N}$ and $\mathrm{P}$ loads per agricultural land. Representative diffuse loads of the watershed are calculated as $15.6 \mathrm{~kg} \mathrm{~N} / \mathrm{ha} /$ year and $0.927 \mathrm{~kg} \mathrm{P} / \mathrm{ha} /$ year as referred in Table 2. These figures lie within the unit diffuse load range for agricultural land as listed in Table 1. 
Table 1 Unit diffuse loads used for various land-use activities

\begin{tabular}{llll}
\hline Diffuse Sources & $\begin{array}{l}\text { Saatci et al. } \\
(1999)\end{array}$ & $\begin{array}{l}\text { Dahl and Kurtar (1993) } \\
\text { and OEJV (1993) }\end{array}$ & Andreadakis et al. (2007) \\
\hline Agricultural land (kg/ha/year) & $0.11-13.45 \mathrm{~N}$ & $10 \mathrm{~N}$ & $40 \mathrm{~N}$ \\
& $0.56-3.03 \mathrm{P}$ & $0.30 \mathrm{P}$ & $0.5 \mathrm{P}$ \\
Forests (kg/ha/year) & $1.45-3.36 \mathrm{~N}$ & $2 \mathrm{~N}$ & $3 \mathrm{~N}$ \\
& $0.56-3.03 \mathrm{P}$ & $0.05 \mathrm{P}$ & $0.1 \mathrm{P}$ \\
Meadows and pasture & & $5 \mathrm{~N}$ & $5 \mathrm{~N}$ \\
& & $0.10 \mathrm{P}$ & $1 \mathrm{P}$ \\
Urban land & & $3 \mathrm{~N}$ & $5 \mathrm{~N}$ \\
& & $0.50 \mathrm{P}$ & $1 \mathrm{P}$ \\
Rural land (kg/ha/year) & $9.50 \mathrm{~N}$ & $9.50 \mathrm{~N}$ & \\
& $0.90 \mathrm{P}$ & $0.90 \mathrm{P}$ & \\
Cows and cattle (kg/animal/year) & $3.80 \mathrm{~N}$ & & \\
& $2.50 \mathrm{P}$ & & \\
Sheep and goats (kg/animal/year) & $1.10 \mathrm{~N}$ & & \\
& $0.20 \mathrm{P}$ & & \\
Poultry (kg/animal/year) & $0.05 \mathrm{~N}$ & & \\
& $0.02 \mathrm{P}$ & & \\
& & &
\end{tabular}

Table 2 Agricultural land, fertilizer applied in each sharing province, and annual loss of excess fertilizers

\begin{tabular}{|c|c|c|c|c|c|c|c|}
\hline \multirow[t]{2}{*}{ Provinces } & \multirow[t]{2}{*}{ Agricultural land (ha) } & \multicolumn{2}{|c|}{$\begin{array}{l}\text { Fertilizer applied } \\
\text { (kg/ha/year) }\end{array}$} & \multicolumn{2}{|c|}{$\begin{array}{l}\text { Loss of excess fertilizer } \\
(\mathrm{kg} / \mathrm{ha} / \mathrm{year})\end{array}$} & \multicolumn{2}{|c|}{$\begin{array}{l}\text { Loss of fertilizer through overland flow and/ } \\
\text { or infiltration }(\mathrm{kg} / \mathrm{year})\end{array}$} \\
\hline & & $\mathrm{N}$ & $\mathrm{P}$ & $\mathrm{N}$ & $\mathrm{P}$ & $\mathrm{N}$ & $\mathrm{P}$ \\
\hline Giresun & 107,416 & 422 & 147 & 63.3 & 7.35 & $6,793,480$ & 789,005 \\
\hline Gumushane & 22,160 & 19 & 6.9 & 2.85 & 0.345 & 64,332 & 7,689 \\
\hline Rize & 54,488 & 952 & 62.2 & 142.8 & 3.11 & $7,777,650$ & 169,500 \\
\hline Ordu & 253,681 & 62 & 9.20 & 9.3 & 0.46 & $2,371,991$ & 116,704 \\
\hline Trabzon & 105,204 & 73 & 7.3 & 10.95 & 0.365 & $1,154,400$ & 38,350 \\
\hline Artvin & 146,174 & 9.82 & 2.01 & 1.47 & 0.10 & 215,303 & 14,722 \\
\hline Erzurum & 562 & 37.29 & 16.38 & 5.59 & 0.819 & 3,142 & 460 \\
\hline Sivas & 2,978 & 37 & 15.04 & 5.55 & 0.752 & 16,591 & 2,239 \\
\hline Tokat & 1,348 & 27 & 33 & 4.05 & 1.65 & 5,383 & 2,197 \\
\hline Bayburt & 2,974 & 2,782 & 178 & 417.3 & 8.9 & $1,240,723$ & 26,402 \\
\hline Watershed total & $1,258,423$ & & & 15.60 & 0.927 & $19,642,995$ & $1,167,268$ \\
\hline
\end{tabular}

Diffuse loads from livestock breeding activities

The animal manure generated from the livestock breeding activities in the watershed is utilized as natural fertilizer in the agricultural activities. Therefore, it is important to know the number of animals and their corresponding manure quantity and quality. The number of livestock breeding animals for 2006 is obtained from Turkish Statistical Institute (TUIK 2006a, b, c).

Animal waste is the only output from the breeding activity as a diffuse polluting source. It is collected and rested for a certain period of time prior to its use as fertilizer on agricultural land. The estimation of the respective pollution loads is done based on the emission factors obtained from the literature. In MoE (2006), the average weight of cow (beef cattle) is stated as $636 \mathrm{~kg}$, cow (dairy cattle) as $431 \mathrm{~kg}$, sheep as $45 \mathrm{~kg}$, and poultry as $2 \mathrm{~kg}$. The fate and behaviour of both natural and commercial fertilizers are almost the same; thus, a certain part of the nutrients is passed on to the water environment by means of run-off and leaching. Therefore, it is assumed that approximately $5-30 \%$ of $\mathrm{N}$ and $0.5-5 \% \mathrm{P}$ is lost. When the same loss values of $15 \% \mathrm{~N}$ and $5 \% \mathrm{P}$ are accepted for the commercial fertilizers, the unit losses of animal manure through water are calculated for typical manure.

The $\mathrm{N}$ and $\mathrm{P}$ loads emitted by manure highly vary according to the animal category, species, nutritional habits and weight of the animal, along with manure characteristics. 
Therefore, it is quite difficult to fix a deterministic unit load. Table 3 shows the values used in the two references cited in the literature with the aim of providing a general idea on the order of magnitudes of the unit loads, and also to demonstrate the selected diffuse loads and the corresponding amount of losses in terms of $\mathrm{N}$ and P. It can be stated that diffuse nutrient loads vary within certain ranges necessitating uncertainty analysis. This statement is valid for all kinds of diffuse nutrient loads arising from the watershed. In the calculation of the diffuse loads arising from livestock breeding, the weight of various animal categories is needed. Cows and cattle are considered as $500 \mathrm{~kg}$, sheep as $45 \mathrm{~kg}$, and poultry as $2 \mathrm{~kg}$ as representative weights of animals for the country by consulting a local livestock dealer and by taking into consideration the weight values as stated by MoE (2006) above.

Diffuse loads from dumpsite leachate, septic tank effluents, and atmospheric deposition including traffic emissions

In the watershed, there are no sanitary landfills; and thus, leachate arising from the dumpsites adds to the diffuse pollution budget. The capita-based solid waste generation for the watershed is calculated as $0.7 \mathrm{~kg} / \mathrm{capita} / \mathrm{day}$. It is assumed that solid waste generation will differ during winter and summer periods as ash arising from heating practices usually increase waste generation during winter, therefore winter values are taken as $0.9 \mathrm{~kg}$, whereas the summer values are considered to be $0.5 \mathrm{~kg}$ in such areas (Ozalp 2009). The corresponding leachate quantity and quality values are calculated based on some assumptions. It is considered that every province within the watershed boundaries own one dumpsite and that they are under operation since 1990. Another important assumption is that there will be no solid waste arising from rural residents as the kitchen wastes are mostly either buried and/or utilized as fertilizer and that other solid wastes are burned via heating. Therefore, only solid waste generation from the urban residential sites are calculated. During the calculation of leachate quality and quantity, the net precipitation values are considered. Table 4 summarizes the estimated solid waste generation values and leachate properties. Details of the calculations are referred in Ozalp (2009).

Part of the urban areas and villages are not connected to sewer system. Therefore, the settlements in the unsewered areas use septic tanks whose effluent is considered as part of diffuse pollutants. The rural population of unsewered areas is multiplied by the water demand per capita $(50 \mathrm{~L} /$ capita/day) to obtain the quantity of water consumed. $80 \%$ of water consumed is assumed as wastewater discharged from the settlements. The nutrient loads of septic tank effluent is then calculated using the typical concentrations depicted in Tchobanoglous and Burton (1991). TKN concentration is $60 \mathrm{mg} / \mathrm{L}$, whereas total $\mathrm{P}$ concentration is taken as $10 \mathrm{mg} / \mathrm{L}$. TKN is assumed to be equal to total $\mathrm{N}$ for the septic tank effluents. Table 5 indicates the raw domestic wastewater unit loads for present and future (year 2024) together with septic tank effluent concentrations.

Regarding the atmospheric deposition in the watershed, the unit value of $10.3 \mathrm{~kg} / \mathrm{ha} /$ year calculated for a similar watershed in the Western Black Sea Region of the country with an annual average precipitation value of $836 \mathrm{~mm} / \mathrm{m}^{2}$ is taken as a representative value, and based on a direct proportion with precipitation, the unit loads of atmospheric deposition for the watershed are calculated for each of the sharing provinces (Ozturk et al. 2007). The unit value for atmospheric deposition (10.3 kg/ha/year) has been achieved after running the air quality model (CORNAIR). It is important to note that the annual average precipitation values for each of the provinces differ in the watershed. The $\mathrm{N}$ load is therefore calculated for each province. It is assumed that $5 \%$ of the overall surface area is affected by atmospheric deposition. The related calculations are given in Table 6.

\section{Results and discussion}

The various types of diffuse loads expressed by nutrients $\mathrm{N}$ and $\mathrm{P}$ are further summed up to achieve the overall figures

Table 3 Manure production rates, selected nutrient values and corresponding losses to the water environment

\begin{tabular}{|c|c|c|c|c|c|c|c|c|}
\hline \multirow{2}{*}{$\begin{array}{l}\text { Animal } \\
\text { category }\end{array}$} & \multicolumn{3}{|c|}{ Total nitrogen (kg/ton of animal weight/day) } & \multicolumn{3}{|c|}{ Total phosphorous (kg/ton of animal weight/day) } & \multirow{2}{*}{$\begin{array}{l}\mathrm{N} \text { loss } \\
\text { (kg/ani./ } \\
\text { year) }\end{array}$} & \multirow{2}{*}{$\begin{array}{l}\text { P Loss } \\
\text { (kg/ani./ } \\
\text { year) }\end{array}$} \\
\hline & $\begin{array}{l}\text { Agricultural } \\
\text { Statistics } \\
(2001)\end{array}$ & $\begin{array}{l}\text { Andreadakis } \\
\text { et al. (2007) }\end{array}$ & $\begin{array}{l}\text { Selected N (kg/ton } \\
\text { of animal weight/ } \\
\text { day) }\end{array}$ & $\begin{array}{l}\text { Agricultural } \\
\text { Statistics } \\
(2001)\end{array}$ & $\begin{array}{l}\text { Andreadakis } \\
\text { et al. (2007) }\end{array}$ & $\begin{array}{l}\text { Selected P (kg/ton } \\
\text { of animal weight/ } \\
\text { day) }\end{array}$ & & \\
\hline $\begin{array}{c}\text { Cows \& } \\
\text { cattle }\end{array}$ & 0.33 & 0.45 & 0.30 & 0.11 & 0.05 & 0.10 & 8.2 & 0.91 \\
\hline $\begin{array}{r}\text { Sheep/ } \\
\text { goats }\end{array}$ & 0.44 & 0.41 & 0.42 & 0.06 & 0.07 & 0.06 & 1 & 0.05 \\
\hline Poultry & 0.67 & 0.33 & 0.52 & 0.24 & 0.22 & 0.22 & 0.06 & 0.008 \\
\hline
\end{tabular}


Table 4 Estimated solid waste generation values and leachate properties

\begin{tabular}{|c|c|c|c|c|c|}
\hline \multirow{2}{*}{$\begin{array}{l}\text { Unsanitary Dumpsites } \\
\text { (Provinces) }\end{array}$} & \multicolumn{2}{|c|}{ Cumulative amount of solid wastes } & \multirow{2}{*}{$\begin{array}{l}\text { Leachate } \\
\mathrm{m}^{3} / \text { day }\end{array}$} & \multicolumn{2}{|c|}{ Polluting loads of leachate } \\
\hline & ton & $\mathrm{m}^{3}$ & & $\mathrm{~N}$ (kg/year) & $\mathrm{P}(\mathrm{kg} /$ year $)$ \\
\hline Giresun & $1,572,938$ & $1,693,933$ & 628 & 91,696 & 2,292 \\
\hline Gumushane & 269,145 & 289,849 & 48 & 353,430 & 8,836 \\
\hline Rize & 605,994 & 652,608 & 519 & 75,788 & 1,895 \\
\hline Ordu & $1,572,938$ & $1,693,933$ & 628 & 91,696 & 2,292 \\
\hline Trabzon & $1,497,430$ & $1,612,617$ & 598 & 69,703 & 1,743 \\
\hline Total & $4,021,015$ & $4,330,324$ & 2,421 & 682,314 & 17,058 \\
\hline
\end{tabular}

Table 5 The raw domestic wastewater unit loads for present and future, and septic tank effluent concentrations

\begin{tabular}{lllllll}
\hline $\begin{array}{l}\text { Unit load for } \\
\text { urban } \\
\text { population (gr/ } \\
\text { cap.day) }\end{array}$ & $\begin{array}{l}\text { Unit load for } \\
\text { rural } \\
\text { population (gr/ } \\
\text { cap.day) }\end{array}$ & $\begin{array}{l}\text { Unit load for urban } \\
\text { population (gr/ } \\
\text { cap.day) for year } \\
2028\end{array}$ & $\begin{array}{l}\text { Unit load for rural } \\
\text { population (gr/ } \\
\text { cap.day) for year } \\
2028\end{array}$ & $\begin{array}{l}\text { Unit load for urban } \\
\text { population (gr/ } \\
\text { cap.day) for year } \\
2039\end{array}$ & $\begin{array}{l}\text { Unit load for rural } \\
\text { population (gr/ } \\
\text { cap.day) for year } \\
2039\end{array}$ & $\begin{array}{l}\text { Septic tank } \\
\text { effluent } \\
\text { concentration } \\
\text { (mg/l) }\end{array}$ \\
\hline $\mathrm{N}$ & 11 & 8 & 12 & 10 & 13 & 11 \\
$\mathrm{P}$ & 1.8 & 1.3 & 2 & 1.6 & 2.2 & 60 \\
\hline
\end{tabular}

Table 6 Estimated unit $\mathrm{N}$ loads and corresponding total $\mathrm{N}$ load arising from atmospheric deposition

\begin{tabular}{llrr}
\hline Provinces & $\begin{array}{l}\text { Annual average } \\
\text { precipitation }\left(\mathrm{mm} / \mathrm{m}^{2}\right)\end{array}$ & $\begin{array}{l}\text { N Load } \\
(\mathrm{kg} / \mathrm{ha} / \mathrm{year})\end{array}$ & $\begin{array}{r}\text { N Load } \\
(\mathrm{kg} / \text { year })\end{array}$ \\
\hline Giresun & $1,259.4$ & 16 & 352,655 \\
Gumushane & 461.5 & 6 & 107,718 \\
Rize & $2,233.5$ & 28 & 544,755 \\
Ordu & $1,041.1$ & 13 & 319,124 \\
Trabzon & 831.3 & 10 & 240,511 \\
Artvin & $1,259.4$ & 16 & 105,665 \\
Erzurum & $1,259.4$ & 16 & 38,746 \\
Sivas & $1,259.4$ & 16 & 38,862 \\
Tokat & $1,259.4$ & 16 & 6,186 \\
Bayburt & $1,259.4$ & 16 & 46,047 \\
Total & $1,301.6$ & & $1,800,269$ \\
& Overall value for the watershed stated & 16 & \\
\hline
\end{tabular}

of the watershed. The distribution of these loads generated according to different activities is shown in Fig. 3.

When the entire watershed is considered, the dominating diffuse $\mathrm{N}$ loads are estimated to be due to the application of fertilizers by $54 \%$, followed by livestock breeding activities by $11 \%$ where the manure is used as natural fertilizers. Almost $7 \%$ of the diffuse $\mathrm{N}$ loads come from meadows and pasture, and $5 \%$ from forests. According to the distribution of the P load, it is estimated that $48 \%$ of the loads arise from agricultural activities and $18 \%$ from livestock breeding. Almost $14 \%$ of diffuse P loads come from septic tank effluents; however, $13 \%$ of the loads are due to rural run-off.

On the other hand, the illustrations given in Fig. $4 a, b$ for $\mathrm{N}$ and $\mathrm{P}$ loads respectively are for alerting the decision makers and other local authorities. These figures point out the distribution of the total diffuse loads arising from each of the sharing provinces. It can easily be observed that Giresun and Rize provinces dominate over other sharing provinces regarding the diffuse $\mathrm{N}$ loads whereas Giresun lead in the diffuse $\mathrm{P}$ loads. As such, similar presentations put forth the distribution of total diffuse loads in the participating provinces.

Control of diffuse pollutants in future

Within the context of this study, projected diffuse load calculations for the future (2028 and 2039) are also calculated by considering and proposing a series of protective actions against further deterioration of the watershed. 
Leachate appearing as one of the minor diffuse polluting sources in the existing situation compared to other diffuse pollutants is recommended to be further diminished in both quality and quantity as the sanitary landfills will be designed and constructed in the near future. The existing dumpsites will then be rehabilitated and sequentially closed. The leachate generated from the sanitary landfills will then act as point sources to be collected and treated.
N Loads from Diffuse Sources in the Watershed

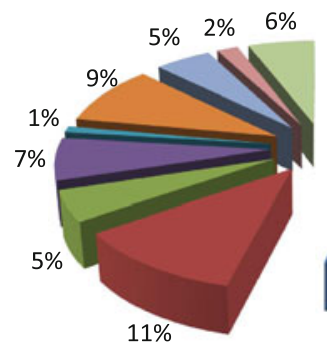

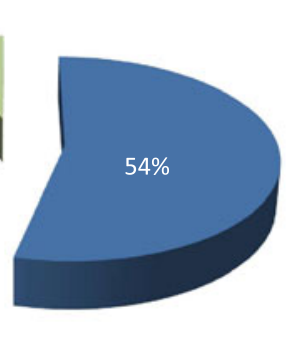

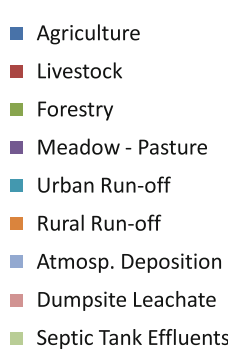

- Agriculture

Urban Run-off

Rural Run-off

- Dumpsite Leachate

Septic Tank Effluents

\section{P Loads from Diffuse Sources in the Watershed}
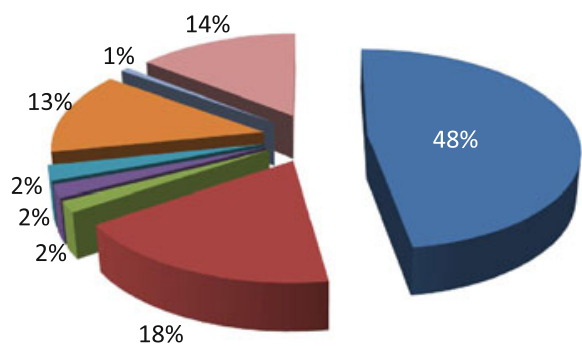

- Agriculture

- Livestock

Forestry

Meadow - Pasture

- Urban Run-off

- Rural Run-off

- Dumpsite Leachate

- Septic Tank Effluents

Fig. 3 Distribution of overall $\mathrm{N}$ and $\mathrm{P}$ diffuse loads of the watershed
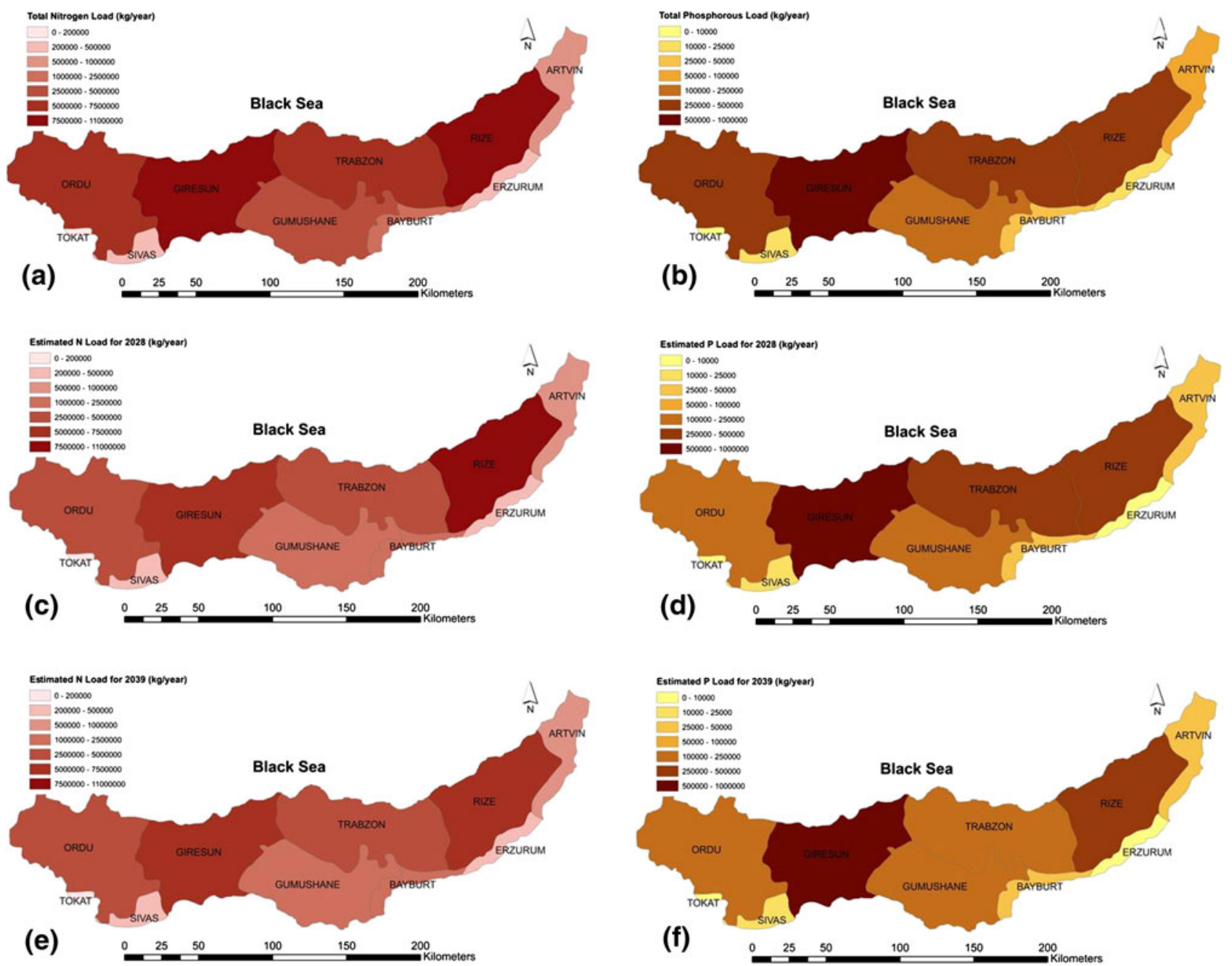

Fig. 4 Distribution of current diffuse $\mathrm{N}$ loads $\mathbf{a}$ and diffuse P loads $\mathbf{b}$; distribution of diffuse N loads $\mathbf{c}$ and P loads $\mathbf{d}$ for year 2028; distribution of diffuse $\mathrm{N}$ loads $\mathbf{e}$ diffuse $\mathrm{P}$ loads $\mathbf{f}$ for year 2039 within the sharing provinces 
The leachate in future will only arise from closed (inactive) solid waste dumpsites as a diffuse source in a decreasing trend (Ozalp 2009). Some of the rural areas will still be using septic tanks rather than installing centralized/or decentralized wastewater treatment plants due to the difficulties faced in the geographical situation of the watershed in future; therefore, a certain amount of rural discharges will be accepted as diffuse sources, but their load will be highly reduced due to population decrease in rural areas as can be followed by the load calculations in Table 5 .

As mentioned previously, coping with diffuse pollutants is a complex task as the pollutants reach to the water environment in a disperse manner. Factors like soil characteristics, climatic conditions and intrinsic properties of fertilizers, manure and forest components (decay material, top soil, etc.) together with the behaviour and fate of the nutrients transported on soil highly affect the transportation mechanisms on soil. Rather, in-watershed controls are considered as effective actions to reduce the nutrient loads that might reach the water environment either through runoff or penetration in soil. It is not possible to completely get rid of diffuse pollutants; however, by taking protective measurements the loads may easily be reduced up to certain extend. Such actions include application of best management agricultural practices like modern irrigation techniques, crop selection, time, frequency and amount of fertilizer applications, switching to organic agriculture where no pesticides and commercial fertilizers are used, appropriate reuse of animal waste in agriculture, and controlling non-agricultural areas.

Presently, in the calculations, it is assumed that there will be a $30 \%$ decrease in the nutrient loads arising from agricultural activities and livestock breeding in year 2028, and $40 \%$ similar decrease in year 2039 based on international experience (Stolze et al. 2000; FAO 2002). The organic agriculture practices reduce the diffuse nutrient loads in a range of $40-80 \%$ within 15 years of practise time compared to values generated in the application of conventional agriculture activities. This range of reduction is valid in developed countries as referred by Stolze et al. (2000). Thus, for a watershed in Turkey, as a developing country, the reduction percentage of $30 \%$ for year 2028 and $40 \%$ for year 2039 is accepted. The most important fact in reduction of nutrient loads will be through organic agriculture and livestock breeding applications. More detailed surveys need to be conducted at the entire watershed in future for the most realistic measures to be taken so as to reduce the diffuse loads in the most effective manner. As such, the load estimations for year 2028 are presented in Fig. 4c, d, and for year 2039 in Fig. 4e, f, for $\mathrm{N}$ and $\mathrm{P}$ loads, respectively with the main aim of illustrating the reductions in a visualized form to attract the interest of decision makers.

\section{Conclusion}

This study displays the determination and estimation of diffuse polluting loads in terms of two nutrients, $\mathrm{N}$ and $\mathrm{P}$, in a watershed characterized by its low population density, negligible industrial facilities, and limited available data to be used in load estimations. The methodology of estimating such pollutants is highly dependent on the areal values of different land-use activities, population, and on unit loads for various activities. This approach emphasizes on a rough approximation of the diffuse pollutant loads; however, more detailed studies can be achieved through watershed modelling applications. In the case of utilizing models, more input data need to be produced which is a tiresome task to handle whenever limited data are available. The benefit of applying such a methodology used in this study is to be able to display the roughly estimated loads per administrative unit composing the watershed which can be demonstrated to the decision makers and other related stakeholders of the watershed including public. Public and state awareness is an important issue in watersheds regarding diffuse loads. Point pollutants are comparatively easier to cope with as their source origin is observable. As mentioned in this study, the provincial-based diffuse pollution can be presented as well as the distribution of loads in the entire watershed. Moreover, some urgent and longterm protective measures are referred in the article with the aim of enlightening the decision makers on the actions to be considered in future. This study will act as a road map for similar future studies especially in developing countries. The subject of concern is part of integrated watershed management activities in the country that is at the EU accession stage.

Acknowledgments The authors of this article would like to thank Istanbul Technical University, Institute of Science and Technology for their support during the preparation of the MSc. Thesis of Ms. Derya Ozalp. This study mainly covers the outcomes of her thesis.

\section{References}

Agricultural Statistics (2001) Animal waste, Wyoming Agricultural Statistics Service, 2001 Wyoming Agricultural Statistics. www.wyomingbusiness.org/pdf/energy/biomass3.pdf

Andreadakis A, Gavalakis E, Kaliakatsos L, Noutsopoulos C, Tzimas A (2007) The Implementation of the water framework directive (WFD) at the River Basin of Anthemountas with emphasis on the pressures and impacts analysis. Desalination 210:1-15

Behrendt H, Dannowski R (eds) (2005) Nutrients and heavy metals in the Odra River System, emissions from point and diffuse sources, their loads, and scenario calculations on possible changes. Weißensee Verlag, Berlin, p 353

Bottcher D, Rhue D (2000) Fertilizer management-key to a sound water quality program, Circular 816, Florida Cooperative Extension Service, Institute of Food and Agricultural Sciences, University of Florida, April 2000. http://edis.ifas.ufl.edu 
Borah DK, Bera M (2003) Watershed-scale hydrologic and non-point source pollution models: review of mathematical bases. Trans American Soc Agric Biol Eng 46(6):1553-1566

Campbell N, D'Arcy B, Frost A, Novotny V, Sansom A (2004) Diffuse pollution, an introduction to the problems and solutions. IWA Publishing, London

Chansheng H, DeMarchi C (2009) Modelling spatial distributions of point and non-point source pollution loadings in the Great Lakes Watershed. World Academy of Science, Eng Technol 54: 795-801

Chapin FS III, Matson PA, Mooney HA (2002) Principles of terrestrial ecosystem ecology. Springer Science and Business Media, USA, p 443

Dahl S, Kurtar B (1993) Environmental Situation, Working Paper, No: 21. Omerli-Elmali environmental protection project-feasibility report, Omerli-Elmali Joint Venture 1.1-5.10, Istanbul

Debarry AD (2004) Watersheds: Processes, Assessment, and Management. Wiley, New york, p 700

Erturk A, Gurel M, Varol E, Ekdal A, Baloch M, Dikerler T, Seker DZ, Tanik A (2007a) Analysis and modelling of land-based nutrient pollution by watershed models coupled with GIS: A case study from Turkey. Water Sci Technol 55(3):115-122

Erturk A, Gurel M, Baloch MA, Dikerler T, Ekdal A, Tanik A, Seker DZ (2007b) Applicability of modelling tools in watershed management for the control of diffuse pollution. Water Sci Technol 56(1):147-154

ESCAP (1997) United Nations-ESCAP, Guidelines and manual on land-use planning and practices in watershed management and disaster reduction

FAO (2002) In: Scialabba, N.; Hatam, C (eds) Organic agriculture, environment and food security, Food and Agriculture Organization of the United Nations. Rome, Italy

Gurel M, Erturk A, Seker DZ, Tanik A, Ekdal A, Avsar C, Ozturk I (2010) Estimation of monthly diffuse nutrient loads for a watershed in Turkey. Water Environ J 25(2):219-229

Hoekstra AY, Chapagain AK, Aldaya MM, Mekonnen MM (2011) The water footprint assessment manual/setting the global standard. Earthscan, UK, p 228

ILEMOD (2007) Modernization Project on the Application and Monitoring of Urban and Rural Infrastructure Services, 292-Fertilizer Application Values per district of the Country, http:// www.ilemod.gov.tr

Karpuzcu M, Agiralioglu N, Alpaslan N, Engin G, Gömann H, Gunduz O, Kocal M, Oncel S, Pekdeger A, Voigt H, Kuhr P, Montzka C, Tetzlaff B, Vereecken H, Wendland F (2008) Integrated modelling of nutrients in selected river basins of Turkey, results of a bilateral German-Turkish research project, Forschungszentrum Jülich GmbH, 183 pg

Kimwaga RJ, Mashauri DA, Bukirwa F, Banadda N, Wali UG, Nhapi I, Nansubuga I (2011) Modelling of non-point source pollution around Lake Victoria using SWAT Model: a Case of Simigu Catchment Tanzania. Open Environ Eng J 4:112-123

Luzio MD, Srinivasan R, Arnold JG (2004) A GIS coupled hydrological model system for the watershed assessment of agricultural non-point and point sources of pollution. Trans GIS 8(1):113-136

MoE (2006) Project on recovery and disposal of animal waste, TUBITAK-MAM, ESCAE, prepared for the Waste Management
Directorate of the Ministry of Environment and Forestry. http://www.atikyonetimi.cevreorman.gov.tr/projeler/gubre.doc

Novotny V (2003) Water quality-diffuse pollution and watershed abatement, 2nd edn. Wiley, New York, p 864

OEJV (1993) Omerli and Elmali environmental protection project, feasibility study, progress report, Omerli-Elmali Joint Venture, Greater Metropolitan Municipality, Water and Sewerage Administration

Oenema O, Roest W (1998) Nitrogen and phosphorous losses from agriculture into surface waters: the effects of policies and measures in the Netherlands. Water Sci Technol 37(3):19-30

Ozalp D (2009) Determination of diffuse polluting sources and management proposals for Eastern Black Sea Watershed. MSc. Thesis, ITU, Institute of Science and Technology, Istanbul, Turkey (in Turkish)

Ozturk I, Tanik A, Cokgor E, Gurel M, Mantas E, Insel G, Ozabali A (2007) Watershed protection action plan, final report, Greater Istanbul Water Supply Melen System II. Stage Buyuk Melen Watershed integrated protection and water management master plan, Istanbul Technical University, Environmental Engineering Department, Istanbul

Pittaway P (2002) How plants acquire nutrients for growth. http://www.australianorganic.com.au/

Saatci Y, Ipek U, Tanyildizi S, Cinarci B (1999) A Research on determination of trophic level of Keban Dam at Uluova Region. National J Water Pollut Control 9/3:41-49 (in Turkish)

Salehi SY, Hajiboland R (2008) A high internal phosphorus use efficiency in tea (Camellia sinensis L.) plants. Asian J Plant Sci 7:30-36

Silgram M, Anthony SG, Collins AL, Stromqvist J, Bouraoui F, Schoumans O, Lo Porto A, Groenendjik P, Arheimer B, Mimikou M, Johnsson H (2009) Evaluation of diffuse pollution model applications in EUROHARP catchments with limited data. J Environ Monit 11:554-571

Stolze M, Piorr A, Haring A, Dabbert S (2000) The environmental impacts of organic farming in Europe, Organic Farming in Europe, 6, Stuttgart. University of Stuttgart-Hohenheim, Germany

Tanik A, Yontar B, Seker DZ (2010) Determination and control of diffuse pollutants arising from watersheds- A case study from Turkey. Fresen Environ Bull 19(10a):2324-2333

Tchobanoglous G, Burton FL (1991) Wastewater engineering: treatment and reuse. McGraw-Hill, Boston

TUIK (2006a) Turkish Statistical Institute, number of cows and cattle according to their types in the country. http://www.tuik.gov.tr/ PreIstatistikTablo.do?istab-_id=681

TUIK (2006b) Turkish Statistical Institute, number of goat and sheep according to their types in the country. http://www.tuik.gov. tr/PreIstatistikTablo.do?istab_id=682

TUIK (2006c) Turkish Statistical Institute, number of poultry according to their types in the country. http://www.tuik.gov.tr/ PreIstatistikTablo.do?istab_id $=688$

TUIK (2008) Turkish Statistical Institute, news bulletin dated 21.08.2008, population values based on year 2007, vol. 9, Ankara. (http://www.tuik.gov.tr)

Wu L, Long TY, Li CM (2010) The simulation research of dissolved nitrogen and phosphorous non-point source pollution in XiaoJiang Watershed of 3 Gorges Reservoir Area. Water Sci Technol 61(6):1601-1616 